\title{
The Imperfect International Sales Law
}

\author{
Time for a New Go or Better Keeping the Status Quo?
}

\author{
Prof. mr. A.U. Janssen and N.G. Abuja*
}

\section{Introduction}

The United Nations Convention on Contracts for the International Sale of Goods (hereafter the 'CISG' or 'Convention') came into effect in 1988 and has been adopted by 91 States worldwide from all continents. Several thousand CISG court decisions and arbitral awards have been published in the meantime. In addition, it has served as a legislative role model for numerous laws at both international and domestic level. ${ }^{1}$ Hence, it seems fair to state that the CISG is a success. The Convention has also had an impact on the legal situation in the Netherlands: The Netherlands is a CISG Member State since 1 January 1992 and the Convention and its predecessors, the two Hague Conventions of 1964 (the LUF and the LUVI) have clearly influenced not only the Dutch Civil Code in general, but also the Dutch national sales law in particular. The comparably large number of published Dutch court decisions and arbitral awards shows that judges and arbitrators apply the Convention without any great hesitation. ${ }^{2}$

However, despite its reach and success, there is, without doubt, considerable room for improvement in the CISG. The so-called Swiss Proposal put forward before the United Nations calling for a new project on international sales law noted that 'the CISG cannot satisfy all the needs of the international commercial community'. ${ }^{3}$ There exist (for various reasons) numerous 'imperfections', a handful of which will be

* Prof. mr. A.U. Janssen is a Professor of Civil Law and European Private Law at the Radboud University Nijmegen, The Netherlands. N.G. Ahuja is a Doctorate Candidate in Law at City University of Hong Kong.

This is a revised and updated version of A. Janssen and N.G. Ahuja, 'The Imperfect International Sales Law: Revamp, Supplement or Leave it Alone?, in P. Sooksripaisarnkit and S. Ramani Garimella (eds.), Contracts for the International Sale of Goods: A Multidisciplinary Perspective, Sweet \& Maxwell 2019, 229-252.

1. I. Schwenzer and P. Hachem, 'The CISG - Successes and Pitfalls' (2009) 57 AJCL 461; A.U. Janssen and N.G. Ahuja, 'Bridging the Gap: The CISG as a Successful Legal Hybrid between Common Law and Civil Law?', in Francisco de Elizalde (ed.), Uniform Rules for European Contract Law? - A Critical Assessment?, Hart 2018, p. 156.

2. However, it seems to be that in Dutch practice the application of the CISG is often (without sufficiently good legal reasons) excluded. See for the application of the CISG in the Netherlands in general R.I.V.F. Bertrams and S.A. Kruisinga, Overeenkomsten in het internationaal privaatrecht en het Weens koopverdrag, 6th edn., Wolters Kluwer, 2018.

3. UNCITRAL, Possible Future Work in the Area of International Contract Law: Proposal by Switzerland on Possible Future Work by UNCITRAL in the Area of International Contract Law, 45th Session, New York, 25 June - 6 July 2012, UN Doc A/CN.9/758 (8 May 2012) 6, https://undocs.org/en/A/CN.9/758, last accessed 8 August 2019. outlined in the subsequent section. These imperfections might form the impetus to revise the body of international sales law. The contribution then prompts the question of whether and if so how the international sales law can be reformed. Interestingly, neither the imperfections of the CISG as such nor the question of reforming the international sales law have gained the academic attention they deserve.

From a bird's-eye view, possible avenues to reform the international sales law, namely supplementation of the existing CISG with (more) hard law instruments or drafting a completely new convention (a 'CISG 2.0') will be examined together with the pros and cons of each method. It will then be revealed whether the CISG ought to be transformed or be left untouched in the first place. From what have been said it becomes clear that the article is going to focus on hard international sales law only while disregarding soft law instruments. This does not, however, mean that soft law instruments such as the Principles of European Private Law (PECL) or the Principles of International Commercial Contracts (PICC) cannot be of any assistance to the (current) CISG, for example by way of interpretation (Art. 7(1) CISG), gap-filling (Art. 7(2) 1. alternative CISG) or maybe even international usages (Art. 9(2) CISG). However, as a lot has already been written about it and hence this is not our focus here. ${ }^{4}$

\section{The CISG's imperfections: so what's wrong with it (and why)?}

The purpose of the CISG according to UNCITRAL, which undertook the project of drafting the Convention, was 'to provide a modern, uniform and fair regime for contracts for the international sale of goods.' Although the CISG is 'the world's most successful substantive international commercial law convention', 6 it is not perfect for several reasons and not even close to it - bearing in mind that a 'perfect' law as such

4. For example: P. Perales Viscasillas, 'The Role of the UNIDROIT Principles and the PECL', in A.U. Janssen and O. Meyer (eds.), CISG Methodology, Sellier European Law 2009, pp. 287-318; P. Perales Viscasillas, 'Interpretation and Gap-filling under the CISG: Contrast and Convergence with the UNDROIT Principles' (2017) Uniform Law Review, pp. 19-28.

5. UNCITRAL, United Nations Convention on Contracts for the International Sale of Goods, Vienna, 1980, https://uncitral.un.org/en/texts/ salegoods/conventions/sale_of_goods/cisg, last accessed 8 August 2019.

6. L.A. DiMatteo, 'Global Challenge of International Sales Law', in L.A DiMatteo (ed.), International Sales Law: A Global Challenge, CUP 2015 , p. 3. 
does not exist anyway. Accordingly, this section lays out a series of 'imperfections' which we have tried to categorize. It differentiates imperfections due to (a) new technological developments the CISG did not foresee, (b) the availability of reservations, (c) practically irrelevant provisions, (d) external and internal gaps of the CISG, and (e) finally the use of open norms and flawed drafted provisions in general.

\section{Imperfections due to new technological developments the CISG did not foresee}

\subsection{General}

There are various technological developments that have (or will in the future) radically transformed business transactions and the way people work, enter into contracts and fulfil their contractual obligations. It therefore probes the question as to whether the advent of technology poses a challenge for the traditional 20th century rules under the CISG. In other words, is the Convention robust enough to reflect the modern world or will it become outdated if it is not revamped or supplemented by other conventions to accommodate new technologies and ways of conducting business? Let us consider the following examples of technological innovations which challenge the CISG in its present form.

\subsection{E-commerce}

E-commerce 'has to do with the form of the contract and covers transactions that are concluded electronically. ${ }^{7}$ The sold items in such transactions can but must not be digital, as surely 'movable goods can also be bought online'. ${ }^{8}$ It goes without saying that at the time the CISG was drafted there was no ecommerce - so the Convention is an offline law while the 21 st century is (also) a digital one. Due to reasons of efficiency and economic pressures it is becoming more and more unlikely that a business does not make any use of the possibilities ecommerce offers, varying from setting up or using sales platforms to at least electronic communication means. But what are the issues that might arise from an international e-commerce contract?

The Convention applies to international contracts, i.e., between parties whose places of business are in different States (Art. 1(1) CISG). In addition, one needs to bear in mind Art. 1 (2) CISG according to which ' $(t)$ he fact that the parties have their places of business in different States is to be disregarded whenever this fact does not appear either from the contract or from any dealings between, or from information disclosed by, the parties at any time before or at the conclusion of the contract'. In an international e-commerce contract the latter requirement might be harder to fulfil than in a regular offline international contract where the internationality of the con-

\footnotetext{
7. V.E. Cserép, 'E Pluribus Unum - Out of Many, One Common Europe an Sales Law?' (2017) 29 Pace International Law Review, p. 229.

8. Ibid.
}

tract is normally obvious. ${ }^{9}$ However, in practice this issue also did not cause serious problems as often in an online scenario, the contracting parties can at least conclude from the disclosed information (and even more so if the E-Commerce Directive, which has been implemented by the Dutch legislator as well, is applicable as it requires that basic disclosures be made for online transactions) ${ }^{10}$ or from the circumstances (e.g. website) whether a sale is international or not. ${ }^{11}$

The CISG describes writing to include 'telegram and telex' (Art. 13 CISG) which are now considered archaic. Electronic communications such as fax (although this mode of communication is starting to orhas already become obsolete) and e-mail are not reflected in the Convention. These days, businesses go as far as instantaneously communicating via modern messaging services and applications such as Facebook, WhatsApp, WeChat etc. due to convenience. In contrast, numerous national jurisdictions and at European level several directives such as the E-Commerce Directive ${ }^{12}$ have admitted the possibility of contract conclusions via electronic means and accordingly to some extent their domestic laws stipulate that an electronic message is deemed to be writing 'provided that it is readable in some form for a human being, even if it is only on the screen' and that it is retrievable in perceivable form. ${ }^{13}$

Also UNCITRAL has acknowledged that 'the CISG may pose obstacles to the wide use of electronic communications.' ${ }^{14}$ For example, Art. 24 CISG stipulates that an offer reaches the addressee when it is made orally to the addressee or delivered by any other means to the addressee personally, to its place of business or mailing address. However, in the context of electronic communication, at what point in time does an offer reach the addressee? The Convention does not specify. Schwenzer notes that the answer would depend on whether 'the receiving party has designated a certain information system or not. If it has done so, the message is received when it enters the information system and can be retrieved by the addressee.' $^{15}$

Similarly, the question of when an offer may be withdrawn in the case of the use of instantaneous communication meth-

9. S. Eiselen, 'The UNECIC: International Trade in the Digital Era' (2007) 10(2) Potchefstroom Electronic Law Journal, p. 71.

10. Art. 5 of the Directive 2000/31/EC of the European Parliament and of the Council of 8 June 2000 on certain legal aspects of information society services, in particular electronic commerce, in the Internal Market (ECommerce Directive).

11. S. Zheng Tang, Electronic Consumer Contracts in the Conflict of Laws, 2nd edn., Hart Publishing 2015, p. 49.

12. See Art. 9(1) of the E-Commerce Directive.

13. S. Eiselen, 'Electronic commerce and the UN Convention on Contracts for the International Sale of Goods (CISG) 1980' (1999) 6 EDI Law Review, p. 36; Tengku Ezuan Ismara ofTengku Nun Ahmad \& Anor v. Lim Seng Choon David (2017) 1 LNS 1840.

14. UNCITRAL, 'United Nations Convention on the Use of Electronic Communications in International Contracts (New York 2005)', https:// uncitral.un.org/en/texts/ecommerce/conventions/ electronic_communications, last accessed 10 August 2019.

15. I. Schwenzer and F.Mohs, 'Old Habits Die Hard: Traditional Contract Formation in a Modern World', (2006) 6 Internationales Handelsrecht, p. 241; Art. 11 (1) 2nd para of the E-Commerce Directive contains a similar criterion. 
ods like e-mail needs clarification. ${ }^{16}$ Art. 15 (2) CISG provides that an 'offer may be withdrawn if the withdrawal reaches the offeree before or at the same time as the offer.' In such case a withdrawal of an offer would never be possible if the offer was sent electronically. The offer would always be received by 'the information system and can be retrieved before the withdrawal reaches the addressee, and this fact can always be traced and proven'. ${ }^{17}$ Hence, due to the use of instantaneous communication methods Art. 15(2) CISG becomes obsolete in practice. What remains is the revocation of an offer under Art. 16 CISG with its more demanding requirements.

\subsection{Intangible items}

Art. 1(1) CISG requires that goods need to be sold to make the Convention applicable, which means that tangible moveable items must be the object of the sales contract. ${ }^{18}$ However, in the digital age, the 'sales' of items such as computer software or more specific mobile apps which are purchased online and downloaded are clearly on the rise. ${ }^{19}$ It goes without saying that these products are intangible and therefore in principle the CISG does not apply to these contracts. There are some exceptions of course. For example, courts and scholars have found the sale of software to fall under the category of goods for the purposes of the CISG so long as the software is contained in a physical or tangible medium such as a disk. ${ }^{20}$ In such cases however, 'the buyer becomes the full owner of the disk' and not the software per se. ${ }^{21}$ Moreover, the software ought to be a standard type, which once developed, could be 'sold' to multiple customers rather than the kind that is customized to an individual customer's specific prerequisites. The latter, i.e. a contract concerning the development of individual software, has been found to be a contract for services pursuant to Art. 3(2) CISG. ${ }^{22}$ On the other hand, some courts have

\section{Ibid.}

17. Ibid.

18. F. Ferrari, 'The CISG's sphere of application: Articles 1-3 and 10', in F. Ferrari, H. Flechtner and R.A. Brand (eds.), The Draft UNCITRAL Digest and Beyond: Cases, Analysis and Unresolved Issues in the U.N. Sales Convention, Sellier. European Law Publishers GmbH / Sweet \& Maxwell 2004, p. 76.

19. Slightly different are streaming services where the customer does not or cannot even download any content anymore (like e.g. Netflix etc.).

20. H. Sono, 'The Applicability and Non-Applicability of the CISG to Software Transactions', in C.B. Andersen and U.G. Schroeter (eds.), Sharing International Commercial Law across National Boundaries: Festschrift for Albert H. Kritzer on the Occasion of his Eightieth Birthday, Wildy, Simmonds and Hill Publishing 2008, p. 518; similarly, although it concerns B2C contracts, see recitals 13 to 16 and Art. 3 of the Directive (EU) 2019/771 of the European Parliament and of the Council of 20 May 2019 on certain aspects concerning contracts for the sale of goods, amending Regulation (EU) 2017/2394 and Directive 2009/22/EC and repealing Directive 1999/44/EC. However, with regard to the latter, Art. 3(4) provides that this Directive shall not apply to any tangible medium which serves exclusively as a carrier for digital content.

21. Sono (n 21).

22. Ibid, p. 519; CLOUT case No. 122 [Oberlandesgericht Köln, Germany, 26 August 1994]; CLOUT case No. 131 [Landgericht München, Germany, 8 February 1995]; UNCITRAL, 'Digest of Case Law on the United Nations Convention on Contracts for the International Sale of Goods', (2016) 7, www.uncitral.org/pdf/english/clout/CISG_Digest _2016.pdf, last accessed 10 August 2019. concluded that any kind of software, including custom-made software should be classified as goods if contained in a physical or tangible medium. ${ }^{23}$ As a result of inconsistent decisions and views, the legal status of digital products remains uncertain to some extent.

When purchasing software, the purpose is to obtain the program and not be concerned with whether it should be obtained on some disk or downloaded or streamed. Treating digital products differently from physical and tangible goods 'fails to meet the businesses' reasonable expectations'. ${ }^{24}$ In contrast to the CISG, the (withdrawn) draft of the Common European Sales Law (CESL) acknowledged the importance of digital products and defined it as 'data which are produced and supplied in digital form, whether or not according to the buyer's specifications, including video, audio, picture or written digital content which makes it possible to personalize existing hardware or software'. ${ }^{25}$ This definition was intended to treat contracts for the supply of digital content de facto the same way as sale of goods contracts and was one of the most innovative features of the CESL. ${ }^{26}$ Also, the Directive (EU) $2019 / 770$ on certain aspects concerning contracts for the supply of digital content and digital services (Digital Content Directive) took over some ideas of the CESL. Art. 2(1) of this Directive defines e.g. the term 'digital content' similarly as the CESL's 'digital product' as 'data which are produced and supplied in digital form'.

\subsection{Smart contracts}

A smart contract was first described by Szabo, as 'a set of promises, specified in digital form, including protocols within which the parties perform on the other promises'. ${ }^{27}$ The general objectives of a smart contract design are to satisfy common contractual conditions (such as: payment terms, liens, confidentiality, and enforcement etc.), minimize exceptions both malicious and accidental, and minimize the need for trusted intermediaries like banks or other kind of agents. ${ }^{28}$ Related economic goals of smart contracts include reducing loss resulted by fraud, enforcement costs, other transaction costs etc. ${ }^{29}$ Essentially, a smart contract is a computer code which contains the terms of the agreement and self-executes

23. CLOUT case No. 281 [Oberlandesgericht Koblenz, Germany, 17 September 1993]; UNCITRAL (n. 23), www.uncitral.org/pdf/english/ clout/CISG_Digest_2016.pdf, last accessed 10 August 2019.

24. R. Bradgate, 'Consumer Rights in Digital Products: A Research Report Prepared for the UK Department for Business, Innovation and Skills', (2010), https://assets.publishing.service.gov.uk/government/uploads/ system/uploads/attachment_data/file/31837/10-1125-consumer-rightsin-digital-products.pdf, last accessed 10 August 2019.

25. Art. 2(j) CESL.

26. C. Willems, 'Obligations of the Parties to a (related) Services Contract', in N. Jansen and R. Zimmermann (eds.), Commentaries on European Contract Laws, OUP, 2018, p. 2085.

27. N. Szabo, 'Smart Contracts: Building Blocks for Digital Markets', (1996), www.alamut.com/subj/economics/nick_szabo/smartContracts .html, last accessed 10 August 2019.

28. N. Szabo, 'Smart Contracts', (1994), www.fon.hum.uva.nl/rob/Courses/ InformationInSpeech/CDROM/Literature/LOTwinterschool2006/ szabo.best.vwh.net/smart.contracts.html, last accessed 10 August 2019.

29. Ibid. 
its obligations upon the performance of a condition or a triggering event. ${ }^{30}$ In the context of international trade, smart contracts might inter alia automate the performance such as to make payment if the goods have been received by the agreed date or to deliver the goods upon receipt of payment.

The challenges for national contract laws worldwide and for the CISG in particular resulting from smart contracts are numerous and cannot be further discussed or outlined here. However, just to give a glimpse of one of the fundamental problems: according to smart contract enthusiasts 'the (computer) code is the law' 31 which means (at least if we take it literally) that smart contracts are functioning without any kind of (contract) law at all - hence private law and therefore also the CISG are redundant to them. Their basic but much disput ed idea is that the computer code is replacing contract law and makes court litigations or arbitrations obsolete as smart contracts are fully self-enforcing.

\subsection{Cryptocurrencies}

Almost always when glancing through the newspapers, there seems to be hardly a day that cryptocurrencies (or utility tokens), especially bitcoins, are not a topic. A cryptocurrency has been defined as 'a digital representation of value that ( $\mathrm{i}$ ) is intended to constitute a peer-to-peer ("P2P") alternative to government-issued legal tender, (ii) is used as a general-purpose medium of exchange (independent of any central bank), (iii) is secured by a mechanism known as cryptography and (iv) can be converted into legal tender and vice versa' ${ }^{32}$ Bitcoins and other cryptocurrencies can be classified in two ways: one is to treat them as items or products which can be purchased, sold or exchanged. The other is that they can also serve as means of payment to purchase goods or services. If cryptocurrencies are sold as per the first classification the result under the current CISG is clear: as cryptocurrencies are digital in nature whereas the Convention applies as mentioned before only to contracts for the sale of tangible moveable goods, the CISG is inapplicable. ${ }^{33}$ Even if we would disregard this aspect (or a future international sales law would extend its applicability to non-tangible items) and cryptocurrencies were to be equated with money Art. 2(d) CISG excludes sales 'of stocks, shares, investment securities, negotiable instruments or money'.

30. See for the legal aspects of smart contracts M. Durovic and A.U. Janssen, 'The Formation of Blockchain-based Smart Contracts in the Light of Contract Law, (2018) ERPL, p. 753; L.H. Scholz, 'Algorithmic Contracts’ (2017) 20 Stanford Technology Law Review, pp. 101-147. For quite a while Szabo's idea of smart contracts was of theoretical interest but with little practical impact as the digital world was not ready for it. This changed radically with the rise of the blockchain technology because it allows smart contracts to use their full potential for automation.

31. L. Lessig, Code Version 2.0,Basic Books 2006, p. 5.

32. R. Houben and A. Snyers, 'Cyptocurrencies and Blockchain: Legal Context and Implications for Financial Crime, Money Laundering and Tax Evasion', (July 2018) 23, www.europarl.europa.eu/cmsdata/150761/ TAX3\%20Study\%20on\%20cryptocurrencies\%20and \%20blockchain.pdf, last accessed 10 August 2019.

33. Ferrari (n 18)
With regard to using cryptocurrency as a form of payment for the purchase of goods, Art. 53 CISG merely requires the buyer 'to pay the price for the goods and take delivery of them'. Under the current CISG it needs to be discussed and decided whether a payment with a cryptocurrency is actually a payment with 'money' - a problem every jurisdiction needs to decide. It is our position that in an international scenario of a delivery of goods for the exchange of cryptocurrency, this could already be considered as a 'payment of money' under the actual CISG. However, if cryptocurrencies are de lege lata, not considered as money under the CISG, such transactions should then be categorized as barter contracts which do not fall within the scope of the actual Convention. De lege ferenda it would be desirable that a future international sales law is going to clarify the issue of cryptocurrencies (or utility tokens) as a payment of money.

\subsection{Verdict}

Probably most of the above-mentioned e-commerce problems can already be resolved de lege lata without necessarily amending the text of the Convention. Some outdated provisions could be effectively 'updated' only by way of interpretation to accommodate modern progress. ${ }^{34}$ For example, the term writing has generally been accepted to 'encompass current, equivalent forms of communication'. ${ }^{35}$ The Advisory Council Opinion no. 1 noted that the term writing includes any electronic communication so long as it is 'retrievable in perceivable form'. ${ }^{36}$ Moreover, although it could be argued that Art. 11 CISG evidently does not offer any scope for alternative paperbased transactions, it does stipulate that a 'contract of sale need not be concluded in or evidenced by writing and is not subject to any other requirement as to form. It may be proved by any means, including witnesses.' Admittedly, there 'is no mechanism which could ensure a uniform interpretation of the $\mathrm{CISG}^{37}$ for the e-commerce problems like a Supreme Court. However, most of the mentioned problems can be solved by interpreting the actual text of the Convention, e.g. also the issue of when an offer or an acceptance 'reaches' the other party using instantaneous methods of communication. Of course this observation does not take away that a codification of these issues can nevertheless be desirable for a future international sales law.

For some other discussed topics like smart contracts it needs to be seen whether they really challenge the fundamentals of the CISG. Our position here is that even in an international smart contract scenario the Convention is applicable and will normally deliver reliable results - at least the CISG

34. Janssen and Ahuja (n 1) 161.

35. K. Steensgaard, Boundaries for Expansive Interpretations of the CISG?, http://pure.au.dk/portal/files/127803095/Boundaries_for_expansive _interpretations_of_the_CISG.pdf, last accessed 10 August 2019.

36. CISG-AC Opinion no 1, Electronic Communications under CISG, 15 August 2003. Rapporteur: Professor Christina Ramberg, Gothenburg, Sweden.

37. S.A. Kruisinga, 'Contracts for the International Sale of Goods: Recent Developments at the International and European Level', (2014) The Dovenschmidt Quarterly, p. 59. 
will not be redundant for this kind of contracts (although due to the self-executing character of smart contracts the focus might shift entirely from remedies prior to the delivery of goods to remedies following the delivery). Another open problem, which is far from being solved de lege lata, is the payment for the delivery of goods by cryptocurrencies. Here the future case law will indicate whether courts and arbitral tribunals are willing to accept this as a payment of money. If this is not the case, a future international sales law needs to decide this topic.

Not all of the above-mentioned topics can be solved solely through the interpretation of the CISG. For example, applying the CISG to digital downloads (or even streaming) by analogy would exceed the boundaries of an (extensive) interpretation of the Convention. This would radically change the sphere of application and such an amendment is neither covered by the wording nor by the will of the drafters of the CISG and its Member States. If the international sales law wants to deal with digital products in the future a new piece of legislation seems to be inevitable.

\section{Imperfections due to the availability of reservations}

\subsection{General}

The possibilities for the Member States to make reservations are other 'imperfections' of the CISG. Arguably the most obvious one is the reservation under Art. 96 CISG. ${ }^{38}$ As mentioned earlier, Art. 11 CISG states that there are no form requirements in the Convention, thereby extending its application to oral contracts. However, Art. 96 CISG entitles States to formally declare that the CISG's freedom of form provision does not apply. Hence, States can declare that a contract or its modification or termination, or any offer, acceptance or other indication of intention have to be evidenced in writing.

Reservations were introduced to give Member States the option to opt out of certain provisions in the Convention to make the CISG more acceptable to them. The impact of the five possible reservations inevitably leads to less uniformity which is contrary to the CISG's purpose of creating a uniform international law for the sale of goods. Furthermore, there is an increased likelihood of confusion regarding the CISG's application'. ${ }^{39}$ The inclusion of reservations can only mean that different 'versions' of the CISG exist and apply and 'present a nasty pitfall for those who expect a nice, congruent single

38. The following States have made an Art. 96 declaration that is currently effective: Argentina, Armenia, Belarus, Chile, Paraguay, Russian Federation, Ukraine and Vietnam.

39. U.G. Schroeter, 'Reservations and the CISG: The Borderline of Uniform International Sales Law and Treaty Law After Thirty-Five Years', (2015) 41 Brook Journal of International Law, p. 227.

40. C.B. Andersen, 'Recent Removals of Reservations Under the International Sales Law - Winds of Change Heralding a Greater Unity of the CISG', (2012) Journal of Business Law, p. 701. text'. ${ }^{40}$ Although, the trend in recent years points towards withdrawals of some or all reservations. ${ }^{41}$

\subsection{Verdict}

Reservations were held to be necessary for the birth and the general acceptance of the CISG - the majority of the declarations were made soon after the Convention came into effect. ${ }^{42}$ The growing trend of withdrawals suggests first that their impact on the application of the actual CISG is clearly decreasing and, secondly, that for a future body of international sales law, the number of reservations could be reduced or eliminated if politically feasible.

\section{Imperfections due to practically irrelevant provisions}

The CISG contains a number of 'dead law provisions'. We would like to highlight some of them. ${ }^{43}$

\subsection{Acceptance not materially altering terms of the offer} Pursuant to Art. 19(1) CISG, it is the rule under the Convention that a purported acceptance which modifies an offer, is a rejection of that offer and instead constitutes a counter-offer. However, an exception to the mirror-image rule is laid out in Art. 19(2) CISG. This provision stipulates that the terms of the acceptance become part of the contract if they do not materially modify the terms of the offer and if the offeror does not object to them. The terms that are considered to be material are identified in Art. 19(3) CISG according to which 'additional or different terms relating, among other things, to the price, payment, quality and quantity of the goods, place and time of delivery, extent of one party's liability to the other or the settlement of disputes are considered to alter the terms of the offer materially'. Bearing in mind this long list with terms which do materially alter the terms of the contract and the strict case law on this, almost all different terms of the acceptance are materially actually altering the original offer. ${ }^{44}$ Hence, the exception made in Art. 19(2) CISG is in practice almost redundant.

41. Since 2011, Finland, Sweden Denmark, Latvia, China, Denmark, Norway and Hungary have withdrawn reservations; although States have also declared reservations such as Vietnam at the time of accession in 2015.

42. Schroeter (n 39), p. 230.

43. The reasons why this 'dead law' was introduced can differ from provision to provision. Some dead law results from the compromise character of the CISG (e.g. Art. 28 CISG) while other provisions were drafted believing that this the best legal solution (probably Art. 19 CISG falls within this category). We have left aside here those provisions which became more or less 'dead law' due to technical developments. They were already discussed before like e.g. the right of withdrawal under Art. 15(2) CISG because of the rise of instantaneous communication.

44. P. Schlechtriem and P. Butler, UN Law on International Sales: The UN Convention on the International Sale of Goods, Springer-Verlag 2009, p. 75 . 


\subsection{Granting specific performance and reasonable excuse}

The CISG foresees the right for specific performance. ${ }^{45} \mathrm{How}$ ever, Art. 28 CISG stipulates that a court is not obliged to grant specific performance under the Convention if it would not do so for similar sales contracts under its domestic law. This poses of course a problem as 'it ostensibly allows each State to apply their own law' - at least for the case of specific performance. ${ }^{46}$ However, there are very few cases mentioning or discussing this provision.

In the event the sold goods are found to lack conformity, the buyer is required to notify the seller under Art. 39(1) CISG or Art. 43(1) CISG within a reasonable time. Failing which, the buyer in principle loses its rights that may arise due to the non-conformity. ${ }^{47}$ However, Art. 44 CISG states that certain remedies (price reduction and damages, except for loss of profits) may be retained if the buyer has a 'reasonable excuse' for its failure to give notice within a reasonable time. The CISG Advisory Council questions effectiveness of the provision as Art. 39 CISG and Art. 43 CISG 'contain language that can fairly be interpreted to reach any result that article 44 was intended to reach. ${ }^{48}$ Case law clearly shows that courts and arbitral tribunals seldom apply this exception and therefore the practical impact of Art. 44 CISG is minor .

\subsection{Verdict}

These briefly mentioned examples demonstrate that some of the Convention's provisions are in practice rarely invoked. They are not only mainly redundant but also often a source of at the end pointless argumentations during litigation or arbitration. For a future international sales law body, 'dead law' provisions should be identified and then removed.

\section{Imperfections due to the external and internal gaps of the CISG}

\subsection{General}

Foreseeing every single legal concern that may arise when entering into a contract is impossible for every contracting party, regardless how much time they invest in drafting. In the absence of a contractual term, the provisions of the CISG (or the applicable domestic law if applicable) function as a 'safety net' for the parties. Thus, in a perfect legal world, at least for international sales law transactions, having 'a one stop shop', i.e., one Convention to refer to and rely upon which covers all legal issues regardless of their qualification would be ideal.

45. The seller and buyer are subject to Art. 28 CISG provided the right to require the party in breach to specifically perform under Art. 62 CISG and Art. 46 CISG respectively.

46. P.J. Osborne, Unification or Harmonisation: A Critical Analysis of the United Nations Convention on Contracts for the International Sale of Goods 1980, (2006), www.cisg.law.pace.edu/cisg/biblio/osborne.html, last accessed 10 August 2019.

47. Janssen and Ahuja (n 1), p. 141.

48. CISG-AC Opinion no 2, Examination of the Goods and Notice of NonConformity: Articles 38 and 39, 7 June 2004. Rapporteur: Professor Eric E. Bergsten, Emeritus, Pace University School of Law, New York.
That said, we know that this is an illusion as the CISG by no means deals with all the matters that can arise from an international sales contract. It is obvious that gaps were left in the Convention. ${ }^{49}$ Here external gaps can be distinguished from the internal gaps.

\subsection{External gaps}

There exist external gaps where the CISG expressly excludes and refers legal issues to be settled by domestic law via the application of private international law (or other applicable conventions) in case the parties did not validly choose the applicable law besides the CISG. According to Art. 4 no. 1 CISG questions of validity such as fraud, misrepresentation, mistake, capacity and illegality are not dealt with by the CISG. The drafters of the CISG had intended for such issue to be governed by domestic laws as it was a difficult task in unifying the law in this area and also politically sensitive. ${ }^{50}$ It would be wishful to harmonize the mentioned issues but it remains perhaps not very realistic that a new body of international sales law would really govern those topics. Almost impossible seems a further harmonization of the excluded property law issues (see Art. 4 no. 2 CISG) and it is not even discussed in this context. However, other areas excluded by the actual Convention, such as the law of agency, assignment of rights, and limitation might be more feasible to include them in a 'CISG 2.0' or more general in a future body of international sales law. There already exist conventions concerning those issues that are designed to interact and complement the CISG non-exclusively, but their impact is still very limited yet as they are lacking Member States or they are not even in force. ${ }^{51}$

\subsection{Internal gaps}

Legal matters, although intended to be governed by but are not expressly settled in the Convention are referred to as internal gaps. ${ }^{52}$ Art. 7(2) CISG comes then in place requiring that these issues are preferably to be settled in conformity with the general principles on which the CISG is based, e.g. for the burden of proof or for the battle of the forms. However, in the absence of such general principles internal gaps are to be filled by domestic law through private international law. A good example therefore is the determination of the interest rate to be paid under the Convention. Art. 78 CISG states that if a party fails to pay the price or any other sum that is in arrears, the other party is entitled to interest on it'. The problem is

49. Janssen and Ahuja (n 1), pp. 141, 148.

50. U.G. Schroeter, "The Validity of International Sales Contracts: Irrelevance of the "Validity Exception" in Article 4 Vienna Sales Convention and a Novel Approach to Determining the Convention's Scope', in I. Schwenzer \& L. Spagnolo (eds.), Boundaries and Intersections: The 5th Annual MAA Schlechtriem CISG Conference, Eleven International Publishing 2014, p. 95.

51. The Convention on Agency in International Sale of Goods (not yet in force); the United Nations Convention on Assignment of Receivables in International Trade; and the United Nations Convention on the Limitation Period in the International Sale of Goods.

52. Mgr. J. Kotrusz, 'Gap-Filling of the CISG by the UNIDROIT Principles of International Commercial Contracts', (2009) 14 Uniform Law Review, p. 130. 
quite obvious: the provision does not specify the method for determining the interest rate. Courts seem to be unable to find a general principle under the Convention as per Art. 7(2) CISG to determine the interest rate and therefore regularly revert to domestic law determined by private international law instead. ${ }^{53}$

\subsection{Verdict}

Various legal issues were excluded from the scope of the CISG as the drafters' 'conflicting views could only be overcome by compromise solutions leaving matters more or less undecided'. ${ }^{54}$ The lesser a future international sales law refers to domestic laws, the greater the harmonization effect. Systemic imperfections can inevitably be observed in every convention - indeed which also a new body of international sales law would probably contain. The systemic imperfections in the CISG are especially explained by the fact that the legal scope needs to be limited. Matters such as transfer of property, tort law, procedural issues, business to consumer contracts, and contracts other than sales contracts are excluded by the Convention. The aim of a future international sales law should be to harmonize as many legal aspects as possible typically for international sales contracts and also cover aspects not governed by the actual CISG. However, an unrealistic view should be avoided as even an improved international sales law might not regulate areas like business to consumer contracts, property law aspects or tort law.

\section{Imperfections due to the use of open norms and flawed drafted provisions in general}

\subsection{General}

One of the main criticisms of the CISG has always been for the use of open norms such as good faith (see Art. 7(1) CISG $^{55}$ and especially the frequent use of the reasonableness standard (see e.g. Art. 39(1) CISG) ${ }^{56}$ or ambiguous terms such as 'fundamental breach' (Art. 25 CISG) ${ }^{57}$ without further defining them. However, this is an issue every codification needs to deal with and is not a CISG-specific problem as Art.

53. P.M. Gerhart, 'The Sales Convention in Courts, The International Sale of Goods Revisited', in P. Sarcevic and P. Volken (eds.), The International Sale of Goods Revisited, Kluwer Law Inernational 2001, p. 99.

54. M.J Bonell, 'The UNIDROIT Principles of International Commercial Contracts and the Harmonisation of International Sales Law', (2002) 36 Revue juridique Thémis p. 340.

55. N. Hofmann, 'Interpretation Rules and Good Faith as Obstacles to the UK's Ratification of the CISG and to the Harmonization of Contract Law in Europe', (2010) 22 Pace International Law Review, p. 178. However, it is debatable whether the good faith is of any value for contracting parties at all as it is only mentioned in Art. 7(1) CISG in a different international public law context.

56. L.A. DiMatteo and A.U. Janssen, 'Interpretive Methodologies in the Interpretation of the CISG', in L.A. DiMatteo (ed.), International Sales Law (n 6), p. 97; L. Tripodi, Towards a New CISG: The Prospective Convention on the International Sale of Goods and Services, Brill 2015, p. 56.

57. L. Graffi, "Case Law on the Concept of "Fundamental Breach" in the Vienna Sales Convention', (2003) 3 International Business Law Journal, p. 337.
6:2 and Art 6:248 of the Dutch Civil Code ('redelijkheid en billijkheid') or $\$ 242$ of the German Civil Code ('Treu und Glauben') demonstrate. Open norms do offer the advantage of flexible interpretation that might be perceived as being more significant than the benefits of enhanced legal certainty. Codifications, however, need to find the right balance in order for open-ended provisions to be treated as a 'double-edged sword' and providing flexibility as well as security for the parties. One can discuss for a future international sales law whether the balance of the current CISG is satisfactory. This topic must also be discussed for a future international sales law, but the use of open norms appears to be inevitable as future developments can never be fully anticipated by the law - only the extent can be questionable.

The CISG also contains some flawed drafted provisions, like conflicting norms. Open price contracts, that is, contracts that can be concluded without explicitly providing for a price is a classic example of a flawed drafted provision. Art. 14(1) CISG excludes any offer from being effective that does not expressly or implicitly make provision for determining the price. However, Art. 55 CISG includes a presumption for contracts without any fixed or provision for determining the price. That is, the parties have impliedly made reference to the price generally charged at the time of the conclusion of the contract for such goods sold under comparable circumstances in the trade concerned'. The two provisions are in conflict and can hardly be reconciled as the former requires for an indication of price whereas the latter implies a price into an open price contract. ${ }^{58}$

\subsection{Verdict}

As has been said before, the use of open norms is inevitable for every codification and even more important for the international sales law because it is more difficult to change or at least update the latter than domestic laws. Hence, also a future international sales law without any doubts needs open norms, only the number of such provisions for inclusion can be discussed. However, it seems that after more than 30 years of the CISG and thousands of published decisions and arbitral awards the open norms of the Convention got in a fairly clear shape. They are at least quite far away from being a black box and deliver workable results. What could be discussed for a future international sales law is whether 'examples' or 'illustrations' (mainly from case law) to the existing open norms should be added - a technique used by some domestic legislators when codifying their private law. Furthermore, it goes without saying that the flawed drafted provisions need to be first identified and then replaced by 'better law' (as e.g. seen from the conflict between Art. 14(1) CISG and Art. 55 CISG).

58. L. Wei, 'People's Republic of China', in L.A. DiMatteo (ed.), International Sales Law (n 6), p. 552. 


\section{Teaching an old dog new tricks or better to get a new one?}

In light of the selected imperfections mentioned in the preceding section, the trick question is what to do with this observation. One option is of course to leave the status quo untouched as the negative consequences of changing the body of international sales law would exceed its positive effects. ${ }^{59}$ If the decision is to revamp the CISG then what are the consequences for international sales law? Assuming that the renovation of the international sales law body is desired, then, should only (more) additional instruments be produced to complement or rather supplement the CISG? Or, perhaps, should a completely new single convention ('CISG 2.0') be created to replace the actual CISG?

This section will touch upon on the two possible avenues. The first is to supplement the CISG through international hard law, leaving the actual version of the CISG untouched. The other is to draft a completely new CISG 2.0. Although the topic can of course not be comprehensively discussed here, some of the advantages and disadvantages of each path will be considered and the practicality of each proposal needs to be measured. ${ }^{60}$ What ought to be taken into account are the needs of international business communities and to weigh them against the factual feasibility in changing the body of international sales law.

\subsection{Supplementation of the CISG through international hard law}

Additional conventions might be embraced to supplement the CISG on 'problematic' areas. The advantage of this method is that the actual CISG remains untouched so there are no different versions of the Convention itself. Another advantage is - seeing it from the perspective of the CISG Member States that they can choose individual 'CISG plus packages' instead of being forced to choose to stay either with the old version or with the future new version of the Convention. ${ }^{61}$ Therefore, one could consider this as the milder means and less radical than drafting a completely new CISG. The idea of supplementation of the CISG through international hard law is not new as for example the Convention on the Limitation Period in the International Sale of Goods or the more recent United Nations Convention on the Electronic Communications in International Contracts ('UNECIC') show. ${ }^{62}$

59. We will come back to this option in the conclusion and try to compare this avenue with the other two option mentioned in this section.

60. Also a combination of both avenues, which means a 'CISG 2.0 plus' supplementing additional conventional law, would be possible.

61. M.J. Dennis, 'The Guiding Role of the CISG and the UNIDROIT Principles in Harmonising International Contract Law', (2013) International Trade / ADR in the South Pacific, p. 48

62. P. Perales Viscasillas, 'Applicable Law, the CISG, and the Future Convention on International Commercial Contracts', (2013) 53 Villanova Law Review, p. 739, 740, 743; United Nations Convention on the Limitation Period (n 51). The aim of the latter is to facilitate the use of electronic communications in international contracts. The UNECIC however does not supplement the CISG exclusively, and therefore conflicting provisions such as the question of validity, which is not dealt governed by the CISG is expressly dealt with by the UNECIC (Tripodi (n 56), pp. 121-122).
The disadvantages of supplementation of the CISG with hard law are numerous and we will just mention some of them briefly. For instance, one must raise the question that - given the various imperfections of the CISG - how many different supplementary instruments will be required to erase the most severe weaknesses of the Convention? The level of defragmentation of the body of international sales law using the mentioned method will probably be considerably higher than when drafting and introducing a complete CISG 2.0. Also, the more conventions governing parts of the international sales law, the more likely it is that the supplementary instruments or some of their provisions are incompatible with each other. In the end it seems that supplementing the CISG through hard law has its virtues, but its flaws are quite serious. This might be one of the reasons that most of the already existing conventions supplementing the CISG are in practice not a big success as States seem to be hesitant to ratify them.

\subsection{Drafting a CISG 2.0}

The second option to revise the actual body of international sales law we would like to discuss is the drafting of a 'CISG 2.0' which is ultimately replacing the actual Convention. It goes without saying that this is long and tedious.

A process similar to the creation of the actual CISG might be required for the setting up of a new Convention. For that undertaking, making the effort as collaborative and transparent as possible throughout the process is key. The process involves a series of steps, which we would like to summarize. The starting point is that UNCITRAL ought to establish a Working Group to carry out an ongoing global public consultation for the purpose of gathering knowledge and particularly, the criticisms of the CISG. ${ }^{63}$ The public consultation would enable various interested parties such as academics, lawyers, governments, institutions, businesses, etc. from worldwide to participate and express their concerns. The Working Group could then scrutinize the imperfections of the CISG that are already identified as well as the newly gathered criticisms from the consultation. At the same time, it could analyze 'the issues arising from the changing circumstances of international trade'64 and also compare with other existing and forthcoming treaties. After which, the Working Group must produce a report of its findings that again would be made public for comments. Alongside, a draft text for the CISG 2.0 together with an explanatory note (the 'Draft') could be prepared, adopting the text of the CISG as the skeleton. ${ }^{65}$ Upon the completion of the Draft, unless new comments have been received, the Working Group would make the Draft public for feedback. UNCITRAL would consolidate 'all the reports, submissions from stakeholders as well as those collected through informal and formal participation of

63. P. Perales Viscasillas (n 62), p. 736, 738: recommended that UNCITRAL undertake the project to assess the viability of a new instrument. 64. Tripodi (n 56), p. 136.

65. H. Deeb Gabriel, 'UNIDROIT Principles as a Source for Global Sales Law’, (2013) Villanova Law Review, p. 669 
broader constituencies with a view to preparing a final version of the Draft for submissions to the diplomatic conference'. ${ }^{66}$

The advantages of a CISG 2.0 are quite clear: a well-balanced, updated CISG 2.0 which covers more factual issues (e.g. downloads and streaming) and legal areas (e.g. set-off, limitation) would not only become the state of the art of international sales law practice, but could also serve as a model for every future law reform worldwide. Both aspects should not be underestimated and especially the latter is often overlooked despite the impact of the actual CISG on national laws. In a perfect legal world such an improved CISG would be ratified quickly by the current CISG Members States, nonMember States would join as well and the CISG 2.0 would in addition become a worldwide model for further law reforms at domestic and international level.

However, we all more or less know that this is an illusion and that another scenario is much more likely, namely that some actual contracting States choose to remain in the CISG and not become party to the CISG 2.0. As a consequence, two sets of conventions might have to co-exist for a long time and declarations and clarifications would have to be considered in practice. The problems arising from overlapping and updated conventions are well illustrated by the field of international carriage of goods with its Hague Rules, Hague-Visby Rules, Hamburg Rules and Rotterdam Rules. ${ }^{67}$ Instead of improving the level of unification and harmonization, a defragmentation of the law is at hand and one can fear this would be the same if a CISG 2.0 sees the daylight - even though it might be argued that the level of defragmentation is at least lower than in the supplementation of the CISG by international hard law scenario. A CISG 2.0 would also lead to more defragmentation and difficult legal questions if the new Convention would deal with topics (e.g. limitation) which are already covered by other Conventions supplementing the CISG. Last but not least, it is likely that a completely new CISG is less acceptable for national States than single conventions supplementing the actual CISG. In the first case, they can only accept or reject all solutions provided by the Convention while in the latter they can cherry-pick and only ratify the Conventions they deem to be acceptable.

\section{Conclusion}

The CISG has as demonstrated numerous weaknesses, some are 'born' weaknesses right from the start, others developed with the technical progress over decades. But is it therefore a bad law? That is a completely different story. Some of the flaws of the actual Convention are unpleasant from an academic point of view and maybe in practice inconvenient, but they do not really affect the final outcome, as for instance the

66. Tripodi (n 56), p. 139.

67. International Convention for the Unification of Certain Rules of Law Relating to Bills of Lading, Brussels; Hague Rules as amended by the Protocol to Amend the International Convention for the Unification of Certain Rules of Law Relating to Bills of Lading; United Nations Convention on the Carriage of Goods by Sea; and United Nations Convention on Contracts for the International Carriage of Goods Wholly or Partly by Sea respectively.
CISG provisions identified as mainly redundant illustrate. In some other cases clarifications would be desirable (e.g. area of international e-commerce), but the CISG demonstrates that it is flexible enough to deal with them in a satisfactory way. Other weaknesses are admittedly painful, especially the gaps of the Convention (e.g. the lacking interest rate in Art. 78 CISG or the excluded validity issues), but it is questionable whether a future body of international sales law would be able to fill these gaps at least partly. For other issues which cannot be solved by interpretation of the CISG one could be de lege ferenda more optimistic, e.g. the inclusion of the sales of digital content. The same is true for the elimination of 'bad drafting'.

The CISG is even in the year 2019 with all its flaws, a workable and worldwide trusted law as proven by the published case law and should therefore not easily be excluded. Still, both introduced alleys to improve the international sales law body, the supplementation of the actual CISG with international hard law or the creation of a CISG 2.0 are legally possible and should openly be discussed. In the end we must balance the inevitable defragmentation and costs for revising the international sales law with the advantages to have a 'better' and more comprehensive body of international sales law. Getting that balance right is a devilishly difficult task which will challenge the international sales law community. At the moment is seems that commemorating the 40th anniversary of the enactment of the CISG is more probable than a CISG 2.0 or the creation of a substantial new body of conventional hard law supplementing the CISG. ${ }^{68}$

68. Tripodi (n 56), p. 140. 